\title{
Eksplorasi Desain Kemasan Berbahan Bambu sebagai Produk Oleh-oleh Premium dengan Studi Kasus Produk Makanan UKM Purnama Jati Jember
}

\author{
Maulana Rizky Hantoro dan Bambang Mardiono \\ Departemen Desain Produk Fakultas Arsitektur, Desain dan Perencanaan, Institut Teknologi Sepuluh \\ Nopember \\ e-mail: beebee@prodes.its.ac.id
}

\begin{abstract}
Abstrak-Fungsi bambu sebagai bahan emasan makanan cukup dikenal luas. Jepang dan Indonesia termasuk dua Negara penghasil bambu terbesar di Asia yang identik untuk kebutuhan. Mengingat Indonesia Negara peringkat ketiga penghasil bambu terbesar di dunia membuat berbagai pihak Bina Usaha memiliki sejumlah program untuk dimanfaatkan sebagai kerajinan, kemasan, furnitur dan lainnya untuk menambah nilai jual bahan baku bambu. Kurangnya pemahaman mengenai pentingnya desain kemasan menjadikan produk olahan Purnama Jati mengalami beberapa permasalahan. Penelitian ini bertujuan untuk memvisualisasikan ide perancangan desain kemasan baru dengan pemilihan material dan bentuk yang didapatkan dari hasil observasi yaitu bambu apus. Jenis-jenis makanan yang dipilih dibuat desain kemasannya adalah suwar-suwir, prol tape, bakpia tape, dodol tape, brownis tape, tape bakar, kerupuk tape singkong, bolu tape, tape goring coklat dan bluder tape. Sebanyak 20 desain untuk produk-produk diatas dengan masing-masing sebanyak dua alternative desain yaitu satu kemasan primer dan satu kemasan sekunder. Berdasarkan hasil riset diatas diperoleh bahwa tidak semua olahan makanan Purnama Jati bias dikemas dengan baik menggunakan material yang sama. Selain itu pembuatan kemasan baru menggunakan desain yang disesuaikan dengan karakteristik makanan membutuhkan waktu dan biaya produksi yang berbeda-beda. Penelitian lebih lanjut dibutuhkan untuk mengetahui kelayakan dan standarisasi dalam penggunaan desain kemasan baru untuk oleh-oleh Purnama Jati. Selain itu penggunaan kemasan baru bias dijadikan sebagai alternative untuk souvenir atau perayaan tertentu.
\end{abstract}

Kata Kunci-Bambu, Kemasan, Purnama Jati dan tape.

\section{PENDAHULUAN}

$\mathrm{K}$ OTA Jember sebagai salah satu tujuan wisata di Provinsi Jawa Timur yang memiliki potensi hasil olahan daerahnya berupa jajanan khas oleh-oleh. Bentuk ini digemari dan dipilih masyarakat karena kepraktisan untuk dibawa maupun disajikan. Kemasan suatu produk oleh-oleh menjadi penting karena desain kemasan dan merk yang menarik memiliki nilai jual yang lebih tinggi.

Menurut Balai Besar Pendidikan dan Pelatihan Ekspor Indonesia, sebanyak $80 \%$ pengunjung atau konsumen membeli suatu barang secara spontan karena melihat kemasan. Dengan demikian, kemasan menjadi salah satu faktor yang secara tidak langsung memaksa para pengusaha makanan, terutama oleholeh di kota Jember untuk meningkatkan penjualan produknya.
Purnama Jati adalah salah satu produsen makanan khas Jember yang turut serta menyadari kondisi tersebut. Telah berdiri sejak tahun 1991, Purnama Jati mengharapkan adanya suatu kesan yang baik, menarik dan bersifat melindungi untuk produkproduk hasil buatannya.

Secara umum kemasan diartikan sebagai hasil mengemas atau bungkus pelindung barang dagangan. Sedangkan menurut [1] kemasan adalah implementasi akhir dari proses mengemas. Kemasan seharusnya memenuhi tiga hal, yaitu memiliki syarat keamanan dan manfaat seperti melindungi produk, yang kedua kemasan dapat menjalankan dan memiliki peran dalam melaksanakan program pemasaran, dan yang ketiga kemasan merupakan suatu cara untuk meningkatkan penghasilan perusahaan.

Berdasarkan struktur sistem kemas, suatu kemasan dibagi menjadi tiga jenis yaitu kemasan primer, kemasan sekunder dan kemasan tersier serta kuarter. Kemasan primer digunakan untuk langsung mewadahi produk olahan. Kemasan sekunder berfungsi untuk melindungi kelompok kemasan primer. Sedangkan kemasan tersier dan kuarter merupakan kemasan yang digunakan apabila masih dibutuhkan pengemasan setelah kemasan primer dan sekuder. Dengan dijelaskan berbagai fungsi dan jenis kemasan yang dibutuhkan untuk membangun identitas sebuah perusahaan, maka dalam riset ini akan divisualisasikan perancangan desain kemasan olahan tape UKM Purnama jati dengan menawarkan alternatif material serta desain kemasan baru yang disesuaikan dengan fungsi pengemasan suatu produk.

\section{METODE RISET}

Dalam penelitian ini akan diperoleh dua macam data yaitu data primer sebagai data kualitatif dan data sekunder sebagai data kuantitatif.

1. Data primer didapatkan dengan cara depth interview kepada narasumber yaitu produsen Purnama Jati serta observasi lapangan terhadap kondisi kemasan oleh-oleh Purnama Jati yang sudah lama beredar.

2. Data sekunder didapatkan melalui data responden dan kuisioner yang dilakukan terhadap beberapa sampel konsumen makanan oleh-oleh Purnama Jati. 


\section{ANALISA HASIL RISET}

\section{A. Analisa hasil depth interview}

Wawancara mendalam dilakukan kepada dua orang narasumber yaitu dari produsen makanan oleh-oleh khas Jember Purnama Jati dan narasumber dari distributor berbagai macam makanan oleh-oleh khas Jember. Secara singkat, baik dari narasumber produsen makanan serta distributor, kondisi kemasan saat ini masih tergolong biasa dan belum adanya upaya untuk berinovasi terhadap tampilan produk.

\section{B. Analisa hasil observasi}

Observasi lapangan terhadap lokasi pusat oleh-oleh khas Jember dilakukan dengan tujuan mengamati kondisi kemasan yang ada di pasaran.

Melalui observasi ini, peneliti dapat mengetahui posisi produk yang dijual serta strategi promosi yang dilakukan. Kondisi konsumen merupakan hal kedua yang didapatkan dari observasi ini.

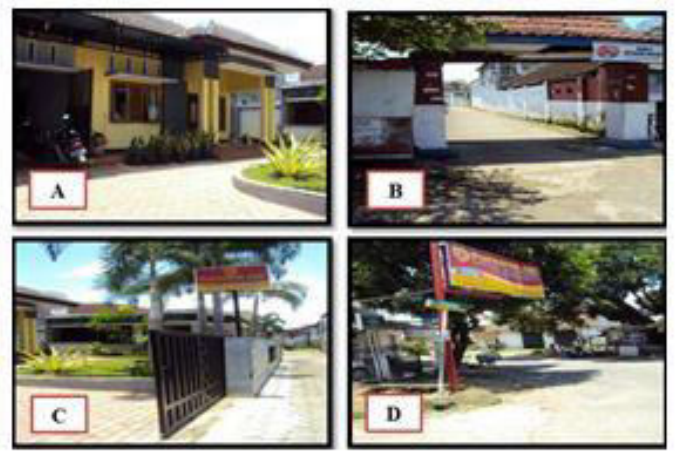

Gambar 1. Konsdisi outlet oleh-oleh khas Jember.

Konsumen cenderung untuk membeli produk yang jelas secara kemasan dan informasi dengan tujuan keamanan konsumsi. Dengan demikian, informasi produk merupakan salah satu bahan pendukung peneliti untuk merancang sebuah kemasan yang juga dapat menyampaikan berbagai informasi terkait produk yang dipasarkan.

Dari hasil observasi juga didapatkan beberapa produk yang tidak mencantumkan informasi jaminan mutu serta bahan material kemasan. Selain itu, penataan produk atau display didalam outlet juga mempengaruhi ketertarikan konsumen dalam memilih produk. Hal terakhir yang belum diperhatikan adalah pertimbangan konsumen mengenai kenyamanan dan keamanan produk yang dibeli untuk dibawa juga menjadi faktor penting untuk merancang sebuah desain kemasan.

\section{Analisa hasil kuisioner}

Berdasarkan grafik yang diperoleh dari data hasil kuisioner, dapat disimpulkan bahwa oleh-oleh kemasan Jember kurang memiliki bentuk yang unik, kemasan tidak memiliki ukuran yang sesaui terhadap isinya, tidak ada simbol serta informasi terkait pada kemasan, kesan yang diciptkan kemasan belum kuat untuk mempengaruhi pembelian produk, umur produk dalam kemasan tidak dapat bertahan lama, produk tidak dapat dikonsumsi jika telah dibuka untuk waktu yang lama, kemasan tidak ramah lingkungan serta kemasan kurang menggambarkan identitaas makanan hasil olahan tape.

Biasanya gambar dan tabel ditampilkan dalam lebar 1 kolom (3 1/2 inci atau 8,89 cm) atau 2 kolom (7 1/16 inci, lebar $17,93 \mathrm{~cm}$ ). Sebisa mungkin ukuran lebar gambar ataupun tabel tidak kurang dari 1 kolom. Hal ini dikarenakan pembesaran yang terlalu ekstrim dapat mendistorsi gambar dan menghasilkan reproduksi yang bekualitas rendah. Untuk itu adalah lebih baik jika gambar yang hendak ditampilkan berukuran sama atau sedikit lebih besar dari 1 atau 2 kolom.

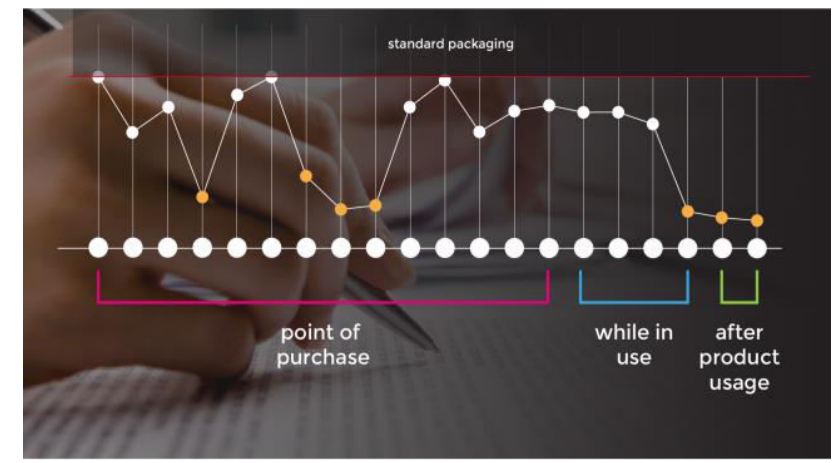

Gambar 2. Hasil Kuesioner Kebutuhan Desain Kemasan.

\section{KONSEP DESAIN}

Konsep desain didapatkan dari hasil analisa beberapa data yang kemudian diperoleh keyword dan output yang akan dieksekusi. Selain itu hasil analisa kuisioner digunakan sebagai kriteria desain dalam riset ini.

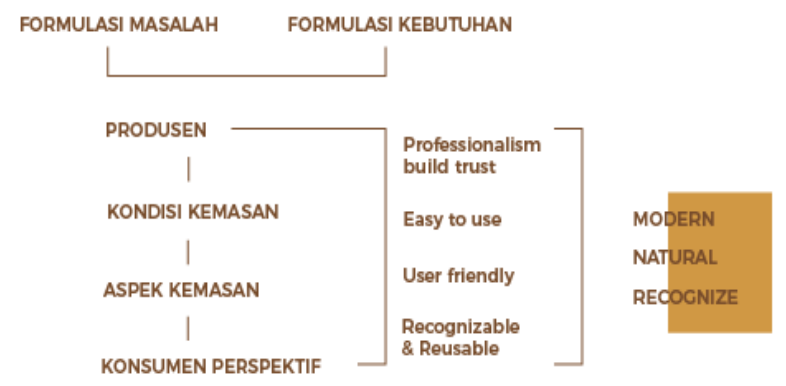

Gambar 3. Struktur Konsep Desain.

\section{A. Media}

Media yang digunakan dalam perancangan kemasan yaitu media utama berupa kemasan primer, kemasan sekunder, kemasan tersier dan kemasan distribusi. Sedangkan media pendukung yang digunakan adalah rak produk, display booth, serta sign pada hasil perancangan.

\section{B. Konsep visual}

Konsep Visual yang digunakan dalam perancangan ini yaitu:

1. Bentuk kemasan produk yang memudahkan pengiriman dan bentuk juga harus bisa meningkatkan daya tarik konsumen.

2. Tipografi yang digunakan pada perancangan ini meliputi penggunaan identitas yang menyampaikan kesan tradisionalitas produk lokal.

3. Warna yang digunakan pada identitas merupakan warna natural yang menggambarkan cita rasa hasil olahan tape singkong yang akan disepadankan dengan media pendukung lainnya. 


\section{Identitas Brand}

Perancangan logo dibuat dengan acuan logo utama produsen yang memiliki arti penting tentang nama Purnama Jati. Pada logo tersebut, penulis mencoba mengembangkan konsep logo yang lebih kental nuansa Jawa Timur dan tetap menjaga makna "purnama" sebagai simbol utama. Pada Logotype "Purnama Jati" penulis berusaha mempertegas dengan menggunakan font "Athene" yang di rubah di beberapa sudut.

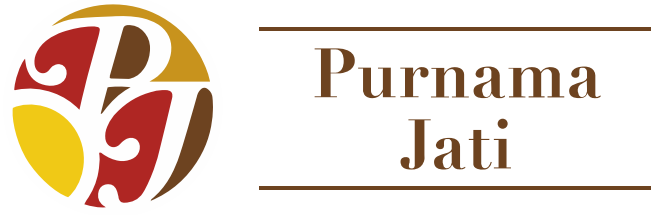

Gambar 4. Identitas visual brand Purnama Jati.

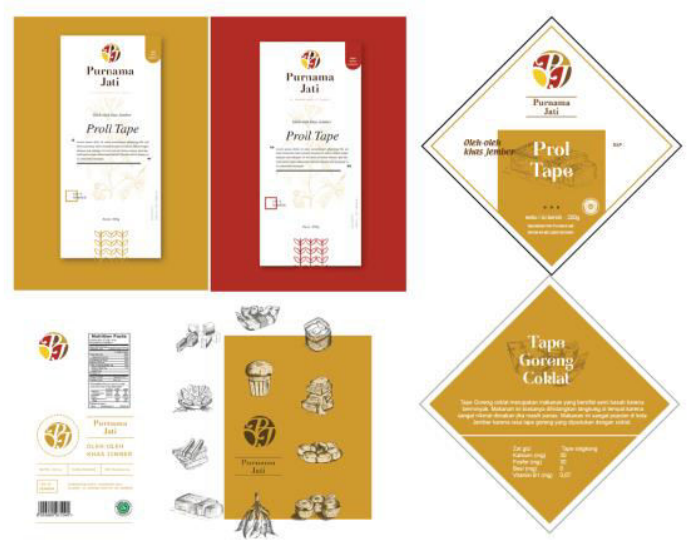

Gambar 5. Alternatif grafis pada kemasan cetak Purnama Jati.

\section{Material}

Material yang digunakan adalah kombinasi antara ketas karton, bahan alam (bamboo dan daun), kertas roti, plastik agar menimbulkan kesan bahwa UKM Purnama Jati merupakan produkoleh-oleh khas kota Jember premium yang dibuat tanpa bahan kimia yang membahayakan.

\section{E. Bentuk}

Bentuk yang digunakan adalah bentukan kemasan modern dengan tujuan memudahkan produsen dan konsumen dalam proses pengiriman serta penataan pada ruang penjualan. Selain itu dari segi fungsi dengan bentukan modern akan lebih mudah dalam penggunaan.

\section{IMPLEMENTASI DESAIN}

Berikut adalah hasil Implementasi desain dari konsep yant telah dibuat :

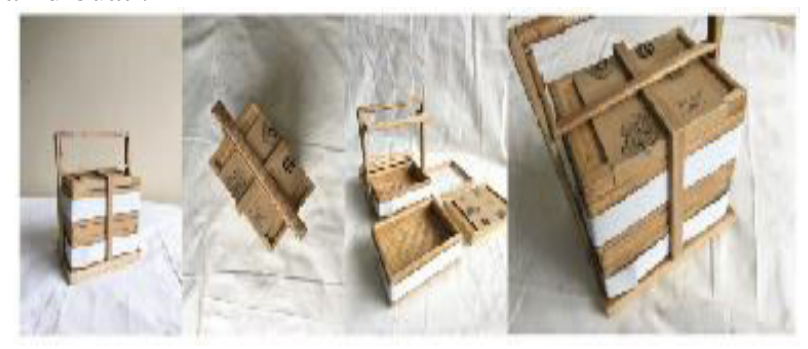

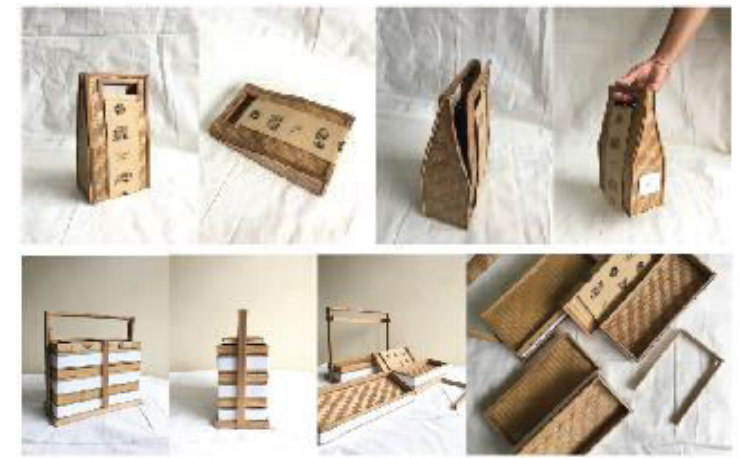

Gambar 5. Implementasi Hasil Desain.

\section{KESIMPULAN}

Berdasarkan penelitian dan pembahasan yang telah dijabarkan pada bab-bab sebelumnya, penuis menarik beberapa kesimpulan, diantaranya sebagai berikut:

1. Produk yang dijual akan memiliki nilai jual yang tinggi jika produsen memperhatikan kemasan makanan yang dijual.

2. Konsumen lebih memperhatikan kemasan yang menarik, informatif dan tidak mengalami kerusakan saat dibawa.

3. Dibandingkan kertas atau plastik, kemasan bambu dinilai lebih ramah lingkungan, efektif dan memiliki berbagai kelebihan.

4. Dalam membuat sebuah kemasan bambu dibutuhkan banyak tahapan dan studi yang diperhatikan agar kemasan sesuai dengan fungsi utama dari kemasan.

5. Beberapa dari bentuk kemasan bambu memiliki pasar yang berbeda karena biaya produksi dan waktu pembuatan yang tidak sama pada setiap kemasan.

6. Kemasan yang baik adalah kemasan yang memperhatikan segi kenyamanan, keamanan dan praktis dalam penggunaan.

Dalam perancangan desain kemasan makanan oleh-oleh khas kota jember ini masih banyak hal yang perlu diperhatikan untuk kedepannya seperti:

1. Informasi yang terdapat pada kemasan sebaiknya lebih detail dan rinci mengenai produk yang dijual

2. Sebaiknya teknis kuncian yang digunakan pada kemasan lebih disempurnakan untuk memudahkan konsumen menyimpan kembali makanan dalam kemasan

3. Hal yang perlu diperhatikan dalam membuat kemasan yang baik salah satunya aspek keamanan kemasan agar tidak melukai tangan ketika dibawa

4. Sebuah kemasan makanan sebaiknya disertakan foto makanan untuk memudahkan konsumen mengidentifikasi jenis makanan di dalam kemasan.

5. Sebuah kemasan bambu akan sangat sulit jika dibuat dengan tidak adanya panduan untuk pengerajin bambu, maka akan sangat membantu jika ditambahkan dengan buku manual agar dapat diproduksi dengan lebih sempurna.

\section{UCAPAN TERIMA KASIH}

Penulis M.R mengucapkan terima kasih kepada Dinas Koperasi dan UKM Jawa Timur, Kepala UKM Purnama Jati Jember, Pengerajin anyaman U.D Puteri Ragil Magetan, 
Dosen Pembimbing, Dosen Penguji, Dan teman-teman ruangan 304 yang telah memberikan dukungan untuk menyelesaikan penelitian tugas akhir.

\section{DAFTAR PUSTAKA}

[1] S. A. Krasovec and M. R. Klimchuk, Packaging Design: Successful Product Branding from Concept to Shelf. San Fransisco: Wiley, 2006. 